\title{
A Brief Contrast of English Academic Book Reviews and English Editorials - from the Perspective of Interpersonal Meaning
}

\author{
Changzhen Ju \\ Wuhan Donghu University, Wuhan, Hubei, 430000
}

Keywords: contrast, academic book review, editorial, interpersonal meaning

\begin{abstract}
Both English academic book reviews and English editorials are full of evaluation resources to express interpersonal meaning. English academic book reviews tend to use more values of appreciation while English editorials tend to use more values of judgement. And academic book reviews use more resources of engagement than editorials to negotiate different stances in the text.
\end{abstract}

\section{Introduction}

Although academic book review and editorials are usually published on different media, actually they have something in common, that is, both of them are trying to make a comment on something. Academic book review is in fact the author's introduction and evaluation on an academic book while an editorial is actually the author's comment on an event or on a controversial topic.

The relationship between language and community is always a central concern of social linguistics. Halliday (2001) insists that language has three metafunctions: ideational, interpersonal, and textual metafunction. That is to say, language can express three kinds of meaning. interpersonal meaning enacts social relations and textual meaning organizes the distribution of information.

\section{The Appraisal Theory}

Martin, White and other professors in the University of Sydney (Martin \& Rose, 2003; White, 1998) developed their research project Write It Right into the model of appraisal during their research. This model is a particular approach to exploring, describing and explaining the way language is used to evaluate, to adopt stances, to construct textual personas and to manage interpersonal positioning and relationships.

The appraisal framework is a functional model of interpersonal meaning at the level of discourse semantics. It accommodates analysis of stance as positioning in relation to values and voices in the text. The model of appraisal includes a system of options for encoding semantics categories of attitude, enabling an exploration of the kinds of values that are encoded in the discourse. It also includes a system of options for grading meanings (graduation), enabling an investigation of how phenomena are valued by degree. And finally, it includes a system of option for expanding or contraction space for other voices in discourse (engagement), enabling an investigation of the dynamic management of other voices by the writer. Appraisal takes attitude as in some sense focus and distinguishes engagement and graduation as distinct resources for sourcing feelings and grading them respectively.

\section{The contrast of English academic book reviews and English editorials on expressing interpersonal meaning}

The tenor of an editorial require that the author must present his attitude towards a topic, thus the author usually uses more values of attitude resources which include three values, affect, judgement and appreciation. In order to be more objective, resources of judgement and appreciation are more often used than resources of affect. This is the same to academic book reviews. Some researchers find that much more values of appreciation are used in academic book reviews while in editorials more values of judgement are applied to present a relatively objective attitude. 
Attitude resources can be categorized into positive and negative resources which are expressed either explicitly or implicitly. In order to present their authority, the authors of academic book reviews use both positive and negative attitudes resources to suggest that their appreciation of a book or criticism of a book after all the tenor of a book review is to give relatively fair evaluation so that potential readers can refer to the book review. Editorials also tend to use both positive and negative resources to clearly show its stance toward certain topic.

However, the interpersonal relationship in academic book reviews is more complicated than that in editorials. The academic book reviews' success is not only contributed to the author's fair review of the contents and value of the book, but also its success depends on whether the author can successfully interact with the potential readers and make his appraisal more convincing. Interpersonal meaning in academic book reviews is how to keep balance between three kinds of groups: the author and the potential readers, the author and the book's author, the readers and the book's author. Therefore, to organize different relationships, academic book reviews use more resources of engagement than editorials. Authors of editorials only need to negotiate their relationship with potential readers, thus they use less engagement to invite readers to participate in the discussion. Their purpose is to promote their own voice and stance.

\section{Conclusions}

Through a brief contrast of academic book reviews and editorials from the perspective of interpersonal meaning, it is suggested that these two genres have different evaluation system except that they both have resourceful values of attitude. This kind of contrast is indispensable to advanced readers because it can help them understand how authors try to persuade readers in their writing so that they can read the authors' attention and attitude more clearly. Moreover, this contrast of different genres is beneficial to writing, especially the writing of argumentation.

\section{References}

[1] Halliday, M.A.K. Language as Social Semiotics: The Social Interpretation of Language and Meaning [M]. Beijing: Foreign Language Teaching and Research Press, 2001.

[2] Kristna Love. Appraisal in Online Discussions of Literary Texts [J]. Text \& Talk, 2006, 26(2): 217-244.

[3] Martin, J.R. \& Rose, D. Working with Discourse: Meaning Beyond the Clause [M]. London: Continuum, 2003.

[4] Sue Hood. Appraising Research: Taking a Stance in Academic Writing [D]. Sydney: University of Technology, 2004.

[5] White, P.R.R. Telling Media Tales: the News Story as Rhetoric [D]. University of Sydney, 1998.

[6] White, P.R.R. Appraisal Guide [OL]. 8 Sep, 2006a. <http:// www.grammatics. com / appraisal/ AppraisalGuide>. 